\title{
Beyond the efficiency-equity dilemma: Centralization as a determinant of government investment in infrastructure*
}

\author{
Daniel Albalate ${ }^{1}$, Germà Bel ${ }^{1,2}$, Xavier Fageda ${ }^{1}$ \\ ${ }^{1}$ Universitat de Barcelona, Facultat d'Economia i Empresa, Torre 6, Planta 3, Avd Diagonal 690, 08034 Barcelona, \\ Spain (e-mail: albalate@ub.edu, gbel@ub.edu, xfageda@ub.edu) \\ ${ }^{2}$ Universitat de Barcelona, Barcelona Graduate School of Economics, Spain
}

Received: 26 June 2011 / Accepted: 27 November 2011

\begin{abstract}
Considerable attention has been given to the efficiency-equity dilemma in explaining the territorial allocation of investment. However, centralization policies that seek to introduce or reinforce territorial hierarchies have yet to be subject to empirical analysis. Drawing on data from Spain, we show that investment in network modes is influenced by strategies of directing funding to the regions immediately surrounding the political capital. These policies of centralization, which complement factors of efficiency-equity trade-off and the satisfaction of political partisan interests, have been facilitated in the case of roads and railways by budgetary funding models in which mobility demands have not been the main driver of investment allocation.
\end{abstract}

JEL classification: H54, R42, R48

Key words: Investment, infrastructure, centralization, redistribution

\section{Introduction}

In recent years economic literature has paid increasing attention to the factors that might explain the regional allocation of public investment in infrastructure (Yamano and Ohkawara 2000; Kemmerling and Stephan 2002, 2010; Knight 2004; de la Fuente 2004; Castells and Solé-Ollé 2005; Cadot et al. 2006; Bel and Fageda 2009; Solé-Ollé 2010). Research in the field has focused particularly on the efficiency-equity dilemma, in conjunction with political partisan interests, in providing explanations of this allocation of investment.

However, by focusing solely on this dilemma, researchers run the risk of overlooking one of the potential objectives of transport infrastructure and services policy, namely, the determination of patterns of political power and the hierarchical structure of territorial administration. In a

* This research has received financial support from the Spanish Ministry of Science and Innovation (ECO200906946/ECON), and the Autonomous Government of Catalonia (SGR2009-1066). Germà Bel thanks support from ICREA-Academia. We have benefited from useful comments by participants in the 2011 ERSA Conference, Albert Solé-Ollé, and three anonymous reviewers. 
stimulating paper, Faguet (2004) sets out to answer the question as to why there is so much centralization in resource allocation. His model locates central government in a particular geographical space, the 'capital', and invokes self-interest on the part of its residents. Although his model does not refer specifically to transport infrastructure, Faguet's claim is that centralization is a consequence of the interests of those that live in the capital city, as they are the ones that benefit directly from a highly centralized government within a context where the constitutional guarantees of territorial government are weak. His model, therefore, introduces a private interest objective above and beyond the public interest objectives of equity and efficiency.

Centralization represents a deliberate attempt to organize a country's communication and transportation networks in such a way that they converge on its political capital. Using infrastructure policy for administrative or political purposes has long been a concern in the economic literature. In a seminal work, Adam Smith identified the fact that public works must be supported by the commerce that is conducted thanks to their existence: "A magnificent high road cannot be made through a desert country where there is little or no commerce, or merely because it happens to lead to the country villa of the intendant of the province, or to that of some great lord to whom the intendant finds it convenient to make his court" (Smith 1776; vol. III.V.I, p. 96).

The use of infrastructure policy to foster centralization has been analysed in the economic history literature for the Australian case (see, for instance, Wotherspoon 1979; Docwra and Kolsen 1989; Gray 2009). Gray concludes that centralization emerged from the political desire to establish and maintain territorial control in the form of a hierarchical governmental and administrative system managed from capital cities. ${ }^{1}$ According to historical evidence presented in Bel (2010, 2011), infrastructure policy in Spain has been driven by an explicit political desire to centralize communications in the capital city. However, to the best of our knowledge, the literature lacks robust empirical evidence to support this hypothesis. We believe that were such an approach to be adopted, considerable light might be shed on the question as to how infrastructure investment is allocated by the central government. This, in turn, should complement analyses that centre on the efficiency-equity dilemma and their extension to a consideration of political factors.

The main contribution of this paper, therefore, is that it provides empirical evidence that centralization objectives, involving the organization of political and administrative power, may have an influence on regional investment that extends beyond that of the efficiency-equity trade-off in some instances. In line with Bel's $(2011,2012)$ historical evidence, Spain proves to be an interesting testing ground for determining whether policies aimed at administrative and political centralization have influenced the regional allocation of investment.

Contrary to what might be expected in a decentralized system of government such as the one operated by Spain, infrastructure policy is highly dependent on central institutions, government as well as parliament. For instance, unlike comparable countries of the OECD, all of Spain's main airports (handling $99.99 \%$ of traffic) are owned and managed by a public entity, AENA, dependent on the Minister for Public Works and Transportation (with responsibility for public works and transportation). The central government is also responsible for all of Spain's commercial ports, virtually all its railways, and the vast majority of high capacity roads, namely, motorways. Consequently, the weight of central government investment over total public investment in Spain is highly significant.

The main results from our empirical analysis indicate that investment programmes in network modes (i.e., roads and railways) are negatively related to distance from the capital city;

\footnotetext{
${ }^{1}$ Other cases of centralized transportation networks, such as that in Argentina, seem to be the result of the developments undergone by private industry, and reflect no deliberate desire on the part of the central government to exercise their control over it (Fleming 1991).
} 
thus, they are influenced by the centralization strategy of investing near the state's political capital. By contrast, investment efforts in non-network modes (i.e., airports) appear to be positively related to distance from the capital. ${ }^{2}$ Note that investment in terrestrial network transportation infrastructure is much higher than that in airports. Besides, investment in network infrastructures in Spain is mainly funded from the budget, whereas investment in airports and ports is almost completely funded from user fees.

This greater interest in the demand factors for non-network modes, together with the fact that point-to-point infrastructure, unlike network modes, does not require any investment in the area lying between two nodes, result in a different pattern of investment allocation. Thus, some regions can receive investment in network modes simply because they lie between two major nodes. For this reason, areas surrounding the political capital may receive more investment that responds to the building of connections from and to the political capital. This being the case, distance from the political capital can be used in studying a country's centralization objective by including it in earlier models of public investment allocation.

Our empirical hypothesis is, therefore, that the centralization objective is confirmed if the public investment in infrastructure undertaken by central government is allocated inversely proportional to the distance from the political capital. This relationship, however, is expected only for network modes (roads and rails), which are the modes financed from the budget.

The rest of the paper is structured as follows. In Section 2, we review the related literature in order to present previous studies of relevance and to place this contribution in the broader context of regional allocation models of public investment. In Section 3, we discuss the main features of recent transportation policy in Spain in order to contextualize our analysis. In Section 4, we explain our empirical strategy by describing the variables, methods and estimation models employed. We present our results and discuss their main implications in Section 5. Finally in Section 6, we draw our principal conclusions highlighting our contribution to the field and identifying points of agreement and disagreement with the existing literature.

\section{Literature review}

The economic literature has paid increasing attention to analysing the factors that might account for the regional allocation of public investment in infrastructure. Initial studies in this vein, such as Yamano and Ohkawara (2000) and de la Fuente (2004), focused on the traditional efficiency-equity trade-off. Other studies, while still concerned with this trade-off, extended their analyses to include political factors as determinants of government investment in infrastructure.

A number of empirical studies, conducted in various European countries, have analysed the determinants of the regional allocation of investment by central governments in transportation infrastructure. Most of these studies have adopted an aggregate approach, where considerations of efficiency, redistribution and equity are captured through the relationship between investment and levels of activity, including regional variables of gross domestic product, stock of capital, and population. This has meant that the use of the infrastructure, which should be measured by the levels of traffic it supports, is typically only included indirectly. Investment in different modes of transportation has usually been taken into account, but analyses have tended to focus

\footnotetext{
${ }^{2}$ Given Spanish geography and the location of Madrid as a political capital occupying a site far from the coast, we chose (on the recommendation of an anonymous referee) to eliminate investment in ports from our analysis.
} 
above all on network infrastructure (road and rail) given the dimension of investment in these two modes.

All these studies include variables related to political tactics or the pressure brought to bear by interest groups that might divert politicians' attention away from the equity-efficiency trade-off. Indeed, it has been widely reported that the regional allocation of infrastructure investment is heavily affected by political questions, while the impacts of redistribution and efficiency vary from one study to the next. Kemmerling and Stephan (2002) show that - in addition to the will to promote equity - the distribution of investment grants among German cities is positively related to the political support the incumbent party enjoys in each city. Castells and Solé-Ollé (2005) and Solé-Ollé (2010) also find that political considerations matter in Spain, where governments tend to invest more heavily in regions where electoral productivity is highest. In this regard, Solé-Ollé (2010) establishes an important distinction between tactical redistribution, so-called pork barrel politics, on the one hand, and programmatic redistribution, based on the citizen-candidate approach, on the other. In his analysis, both tactical and programmatic decisions influence the investment decisions of Spain's central government. Cadot et al. (2006) conclude that the regions in France with the highest marginal productivity of investment do not necessarily receive any more investment, while the influence of certain interest groups (measured by the number of large companies based in the region) or political factors, such as the difference in votes recorded by the two main political parties, have a marked impact on such decisions.

Kemmerling and Stephan (2010) emphasize the importance of country-specific political institutions in order to explain the regional distribution of investment. In analysing this, the authors undertake a cross-country empirical study of France, Germany, Italy and Spain. The results of their empirical estimation suggest that efficiency concerns are important in all four countries, and that redistribution is likewise a common key objective (albeit not statistically significant in the case of France). However, their results concerning the equity objective are more ambiguous, and no unequivocal conclusion can be drawn. Overall, they find considerable diversity in relation to the effects of political variables, though they identify two general trends: (i) ideological variables only play a significant role in centralized systems; and (ii) electoral incentives play a role in most countries.

A further group of studies focuses their attention on non-network transportation modes (airports and ports). As they examine a specific mode of transportation, their analyses of efficiency can include variables directly related to traffic. In this regard, Bel and Fageda (2009) found that regional investment in Spain's airports was driven by neither considerations of redistribution nor those of efficiency, while political variables (electoral support for the incumbent party in the national government, party alignment in national and regional governments) played a significant role. Furthermore, Castillo-Manzano and Fageda (2010) also found that party alignment influences regional investment in Spain's ports.

As for the US, Bilotkach (2010) concludes that it is tactical political factors rather than economic factors that determine regional investment in airports. Similarly, Knight (2004), in analysing congressional voting on the funding of transportation projects, finds that the probability of supporting such projects increases in cases of own-district spending.

Recent studies examining the regional allocation of investment in transport infrastructure have incorporated new political variables, thereby adding to the traditional debate as to whether considerations of efficiency and/or equity determine these investments.

To the best of our knowledge, our analysis includes an entirely new variable concerning the centralization hypothesis, which has not previously been tested in any empirical paper on the regional allocation of investment made by central government. In this regard, it is our claim that a central government can simultaneously pursue several objectives, including that of greater centralization. 


\section{Transportation infrastructure policy in Spain (1978-2010)}

An interesting question to emerge from earlier studies is that of how best to approach the criterion of efficiency. While relating regional output to the region's infrastructure stock seems a sensible way to approach the issue in an aggregated manner, the methodology would clearly benefit from undertaking a more detailed disaggregated analysis. Rich regions do not always have high project impact, and by the same token poor regions do not always have low project impact. Rather impact crucially depends on the previous stocks of a given type of infrastructure.

For instance, Spain's motorway plan (1984-1991, see Figure 1) in stressing investment in areas where high capacity roads were absent was, in all likelihood, adhering to a criterion of efficiency. However, the fact that some of the roads that were transformed into toll-free motorways, and which linked Madrid with other cities in Spain, had lower traffic intensity than others in poorer areas that were not transformed into motorways (Bel 2010, pp. 151-154) would run counter to considerations of efficiency and equity. All in all, the deputy minister for ground transportation infrastructures, Emilio Pérez Touriño (1994, pp. 14-15) provided a clear account of what building the autovías as part of the General Road Plan (Plan General de Carreteras) 1984-1991 had meant: "It is a network that has endowed our country's radial nature with high-capacity roadways [...] in terms of high-capacity infrastructure, the network has concentrated on completing the radial connections in our country, in addition to a number of other key actions". However, what really matters as far as efficiency is concerned is not whether a region is rich or poor, but whether its traffic intensity (i.e., average daily traffic) matches its existing motorway capacity (current level of service).

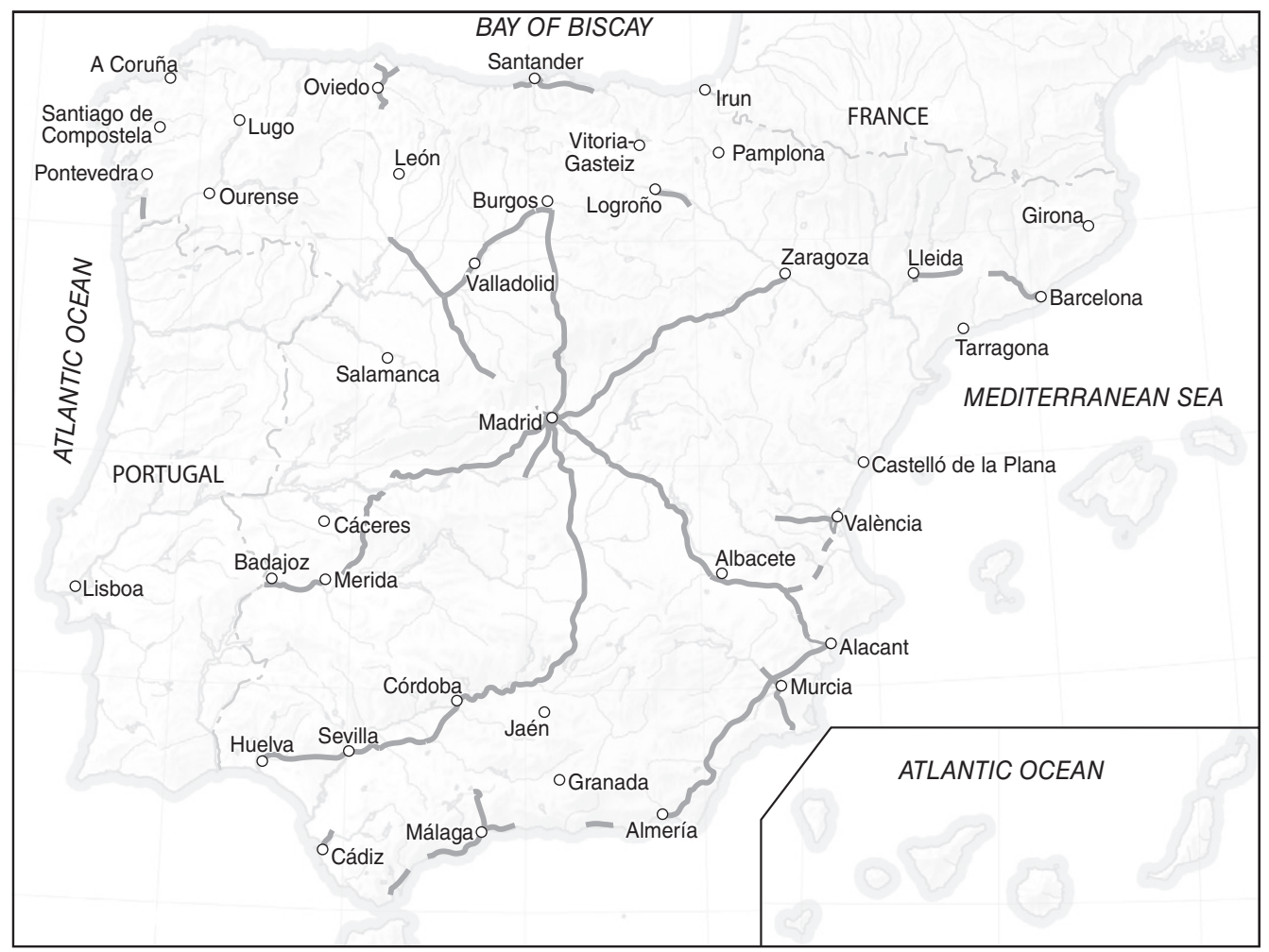

Fig. 1. Toll-free motorways opened until 1993 as a result of the PGC (1984-1991) Note: Routes in service wide line. Routes projected until 2020 thin line. 


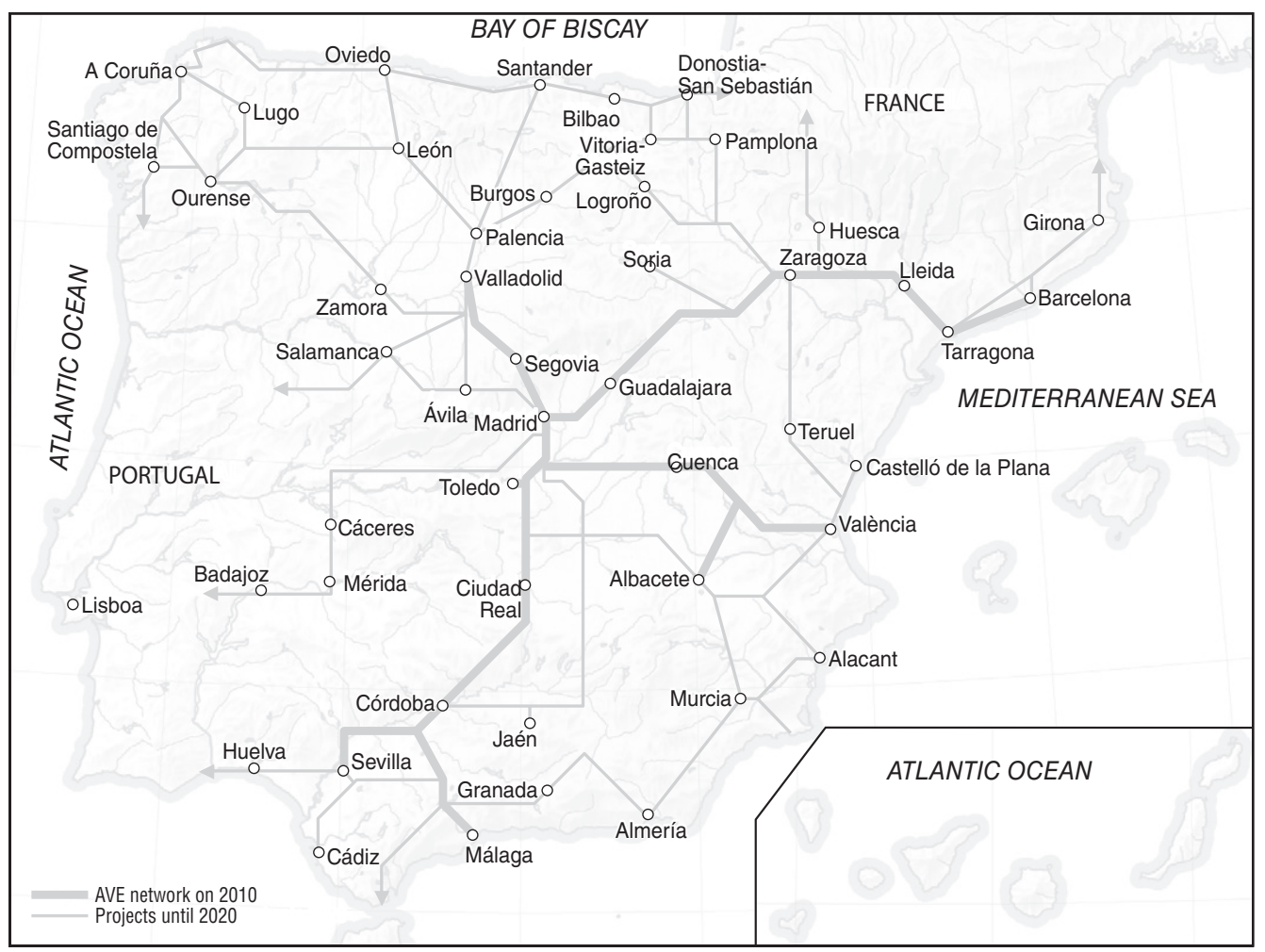

Fig. 2. High Speed Rail network in Spain

A more explicit desire to centralize infrastructure policy was expressed by Rafael Arias-Salgado, Minister for Public Works and Transportation (Ministro de Fomento) in the first government of the conservative Popular Party (1996-2000). On 29 September 1997, the minister met with the Popular Party's National Committee for Infrastructure. Arias-Salgado stated that the government's infrastructure policy was designed with "the intention of strengthening the centre of the peninsula" and that the main priority of his Ministry was "to set in motion a series of investments that are determined by what we might call the 200-kilometre belt around Madrid and the connection of certain regions of Spain with the centre of the peninsula."

Furthermore, the president of the government, José María Aznar, in his (second) investiture speech given on 25 April 2000, having won an absolute parliamentary majority in the March elections of that year, stated that his priority in terms of spending on infrastructure was "a high-speed railway system that, in ten years, will locate all the provincial capitals within a four-hour distance of the centre of the peninsula."4 This policy statement was subsequently very closely reflected in the decisions taken regarding infrastructure funding. This was the case of the extension of the high speed rail (HSR) network in Spain, as shown in Figure 2. Investment in the HSR has been funded entirely from the public budget, and yet operational revenues do not fully cover operational expenditure.

\footnotetext{
${ }^{3}$ Minutes of the meeting of the Comisión Nacional de Infraestructuras para las Comunicaciones of the Partido Popular, 29 September, 1997.

4 José María Aznar, Debate sobre la investidura del candidato a la Presidencia del Gobierno. Diario de Sesiones del Congreso de los Diputados. Pleno y Diputación Permanente. 2000, nº 2 (25 April), p. 29.
} 
In principle, considerations of redistribution and political objectives are more likely to influence decisions concerning budget-funded infrastructure than they are to influence infrastructure paid for by users. In Spain, in recent decades, note that, as a rule, surface transportation networks have tended to be funded from the budget. However, airports and ports have - in the main - been funded by user charges (albeit by employing cross-subsidy schemes), as in most developed countries. Thus, a disaggregated analysis according to infrastructure type is likely to provide more robust results.

It is our belief that the approach we adopt here - focusing our attention specifically on the centralization objective - should facilitate an understanding of how infrastructure investment is allocated by the central government, supplementing analyses based on the efficiency-equity dilemma and a consideration of political factors. By taking this road, our approach is consistent with centralization as a political objective of infrastructure policy in Spain, which has been found as a regular pattern in the last three centuries regarding surface network transportation infrastructures in works such as Bel $(2011,2012)$.

\section{Empirical analysis}

\subsection{Data and variables}

First, we describe the variables used in the empirical analysis and identify the sources drawn upon. The data for each of these variables were obtained at the Spanish provincial level, which means we have information for 50 provinces (provincias) and the autonomous city of Melilla, ${ }^{5}$ for a period that runs from 1981 to 2005 . In total, we have 1,275 observations. The main variables are the following:

\subsubsection{Dependent variable}

Our main concern is to identify the determinants of central government investment efforts during the period studied. Therefore, our dependent variable is the gross investment per capita in transportation infrastructure made by central government $(i)$. Information for investment was obtained from the Fundación BBVA-Instituto Valenciano de Investigaciones Económicas (FBBVA-IVIE) website (URL: http://www.ivie.es). Data are expressed in thousands of current euro and are available for each transportation mode: roads, railways, airports and ports. We exclude from this analysis investment in ports, since it is determined by geographical conditions. Given that Madrid is situated in the geographic centre of Spain (unlike most political capitals in Europe, which enjoy close access to water transportation modes), a coastal location would determine the results of the distance variable, and geographical conditions are not the focus of our analysis here.

\subsubsection{Regressors}

1. Distance between the centre of each region's capital and Madrid's city centre (Distance_capital). The data for this variable were computed using the algorithm of Google

\footnotetext{
${ }^{5}$ We have not included the autonomous city of Ceuta (on the North African side of the Strait of Gibraltar) as data were missing for several variables.
} 
Maps in which we calculate the shortest route in kilometres by road. This variable measures the central government's centralization objective.

2. Gross domestic product per capita in the previous year (GDP_per_capita). Information for this variable was obtained from Spain's institute of statistics, the Instituto Nacional de Estadística (INE) (URL: http://www.ine.es). Data are expressed in thousands of current euro. This variable captures economic wealth and, as such, it measures whether the central government invests more in poorer regions. In an effort to overcome any endogeneity, we use the first lag of the GDP per capita. Information for this variable was also obtained from the FBBVA-IVIE website.

3. Nominal stock of capital in the previous year (Stock_capital). Information for this variable was obtained from the FBBVA-IVIE. This variable captures the role of the existing infrastructure in a given province in the allocation of investments by the central government.

4. Percentage number of votes obtained by the incumbent party in central government at the elections to the central parliament across regions (Votes). Information for this variable was obtained from the Ministry of Domestic Affairs' website (URL: http://www.mir.es. This variable captures the opportunistic political behaviour of the incumbent party in central government.

5. Population (Population). Information for this variable was obtained from the INE. Data are expressed in terms of the total number of inhabitants in thousands. This is a measure of mobility needs and transportation demand. Therefore, this is a variable related to the efficiency objective of investment allocation. Information for population was obtained from the INE.

6. Land area of the province (Land). Information for this variable was obtained from the INE. Data are expressed in terms of square kilometres and provide a further measure of mobility needs and accessibility. As such, this is also a variable related to the efficiency objective of investment allocation.

7. Some regions in Spain enjoy powers and jurisdiction in the management of certain infrastructure. In these regions central government has less investment presence owing to the political decentralization. To identify these regions with responsibility for infrastructure investment we use the binary variable $D^{\text {foral }}$.

\subsection{Estimation strategy}

We performed several estimations to test our main hypotheses. First, we regressed total investments on several groups of determinants (Model 1) so as to analyse the political objectives of redistribution, efficiency, centralization and electoral opportunism (i.e., our policy regressors), as well as a number of other control variables. The centralization objective was determined using the distance from the capital to the province receiving investment as our covariate. Thus, to confirm our hypothesis, we expected a negative relationship between this variable and the total investment effort. Likewise, a negative correlation between the lag of the GDP_per_capita and total investment effort would mean that central government invests more resources in poorer regions.

Since the literature also suggests that the government (or incumbent party) tends to favour the political communities from which it receives most electoral support, we introduced this opportunistic behaviour by including the Votes variable in the model. Here, we expected a positive relationship between the percentage of votes polled by the incumbent party of central government and the amount of investment in the corresponding province.

Among the control variables, two groups of regressors can be distinguished. The first group is formed by covariates that capture mobility needs, namely Population and land area (Land). In 
this regard, we expect investment efforts to be positively associated with mobility needs. The transportation literature usually considers efficiency in infrastructure transportation by relating traffic intensity to existent capacity. Since it is not possible to obtain homogeneous traffic data for each mode of transportation, we use population and land area as reasonable proxies of potential demand of mobility.

The second group of regressors contains a dummy variable $\left(D^{\text {foral }}\right)$ denoted with a value of 1 for the provinces that have jurisdiction - due to political decentralization - over the network modes of road and rail transport and 0 otherwise. Indeed, the regional governments of Basque Country and Navarra are in charge of investments in these transportation modes. ${ }^{6}$ The remaining Spanish provinces only have responsibility for investment in secondary roads in the period considered. This binary variable $\left(D^{\text {foral }}\right)$ should have a negative impact on central government investment in those transport modes under the jurisdiction of regional governments. Given that these modes are surface network modes, accounting for most of central government investment, this negative relationship is expected to be marked. Finally, the variable built as the lag of stock of capital will show us whether territories with a better endowment of transport infrastructures receive more or less resources. Below we present the specification of Model (1).

$$
\begin{aligned}
i_{i t}^{t^{\text {total }}=} & \alpha+\beta_{1} \text { Distance_capital }_{i}+\beta_{2} \text { GDP_per_capita } \\
& \beta_{4} \text { Votes }_{i t}+\beta_{5} \text { Population }_{i t}+\beta_{6} \text { Land }_{i}+\beta_{7} \text { Stock_Capital }_{i t-1}+{ }_{i}+\varepsilon_{i t}
\end{aligned}
$$

Although we tested our hypothesis on the political objectives that successive Spanish central governments set themselves in their investment programme design, recall that we are also interested in identifying the statistical impact of the various modes of transportation so as to show that a consideration of total investments on their own can lead to a misinterpretation of results. Thus, in Models (2) and (3) we replicated the estimation strategy, but this time we differentiated between network modes (roads and rail) and airports, respectively, so as to account for the different characteristics of network and non-network infrastructure. These two models aggregated by mode are presented below:

$$
\begin{aligned}
i_{i t}{ }^{\text {network }}= & \alpha+\beta_{1} \text { Distance_capital }_{i}+\beta_{2} \text { GDP_per_capita }_{i t-1}+\beta_{3} \text { Stock_Capital }_{i t-1}+ \\
& \beta_{4} \text {.otes }_{i t}+\beta_{5} \text { Population }_{i t}+\beta_{6} \text { Land }_{i}+\beta_{7} D^{\text {foral }}{ }_{i}+\varepsilon_{i t} \\
i_{i t} \text { airports } & \alpha+\beta_{1} \text { Distance_capital }_{i}+\beta_{2} \text { GDP_per_capita }_{i t-1}+\beta_{3} \text { Stock_Capital }_{i t-1}+ \\
& \beta_{4} \text { Votes }_{i t}+\beta_{5} \text { Population }_{i t}+\beta_{6} \text { Land }_{i}+\beta_{7} D_{i}^{\text {foral }}+\varepsilon_{i t}
\end{aligned}
$$

Note that our estimation excludes the island provinces from the sample since, given that our main aim is to distinguish the different policy objectives pursued by central government. Including islands in estimations that consider surface network modes could distort the results of the Distance_capital variable.

\section{Estimation and results}

Tables 1 and 2 show the descriptive statistics and the correlation matrix for the main variables used in the empirical analysis, respectively. From these tables, we can see that all the variables present sufficient variability, while the multicollinearity between regressors did not seem to pose a problem.

\footnotetext{
${ }^{6}$ Four provinces are included in these two regions: Álava, Guipúzcoa, Navarra and Vizcaya.
} 
Table 1. Descriptive statistics of the variables used in the empirical analysis

\begin{tabular}{lrccc}
\hline Variable & Mean value & Standard deviation & Minimum value & Maximum value \\
\hline$i^{\text {total }}$ & 125.86 & 164.36 & 1.96 & $1,759.53$ \\
$i^{\text {network }}$ & 112.02 & 162.21 & 0 & $1,759.53$ \\
$I^{\text {airport }}$ & 12.74 & 23.12 & 0 & 272.52 \\
Distance_capital & 426.53 & 320.81 & 0 & 1770 \\
GDP_per_capita & $9,702.98$ & $5,566.76$ & 825.71 & $28,971.92$ \\
Stock_capital $\left(K_{t-1}\right)$ & $1,979,153$ & $2,604,734$ & 16,268 & $3.17 \mathrm{e}+07$ \\
Land & $10,162.75$ & $4,847.82$ & 12.3 & 21,766 \\
Population & 200.80 & 687.15 & 8.82 & $5,624.71$ \\
Votes_Incumbent_Party & 41.89 & 9.87 & 15 & 66 \\
\hline
\end{tabular}

Table 2. Correlation matrix of the variables used in the empirical analysis

\begin{tabular}{|c|c|c|c|c|c|c|c|c|}
\hline & $i^{\text {total }}$ & $i^{\text {net. }}$ & $I^{\text {airport. }}$ & Dist. & $G D P c$ & $K_{t-1}$ & Land & Population \\
\hline$i^{\text {total }}$ & 1 & & & & & & & \\
\hline$i^{\text {network }}$ & 0.98 & 1 & & & & & & \\
\hline$I^{\text {airports }}$ & 0.06 & -0.04 & 1 & & & & & \\
\hline Dist. & -0.12 & -0.14 & 0.29 & 1 & & & & \\
\hline$G D P p c$ & -0.06 & -0.07 & 0.25 & -0.003 & 1 & & & \\
\hline Stock_Capital $\left(K_{t-1)}\right.$ & 0.18 & 0.18 & 0.13 & -0.02 & 0.36 & 1 & & \\
\hline Land & 0.19 & 0.22 & -0.26 & 0.32 & -0.19 & -0.19 & 1 & \\
\hline Population & -0.08 & -0.12 & 0.32 & 0.10 & 0.09 & 0.02 & -0.15 & 1 \\
\hline Votes & 0.17 & 0.18 & -0.01 & -0.06 & -0.16 & -0.07 & 0.40 & -0.03 \\
\hline
\end{tabular}

Note: In the computation of correlations, we excluded provinces located on islands.

Table 3. Specification tests

\begin{tabular}{lr}
\hline Breusch and Pagan Lagrangian multiplier test for random effects & $\mathrm{Chi}^{2}$ \\
\hline Total investments & $116.06^{* * * *}$ \\
Network investments & $116.42^{* * * *}$ \\
Airport investments & $35.71^{* * * *}$ \\
\hline Wooldridge test for autocorrelation in panel data & $\mathrm{F}(1,46)$ \\
\hline Total investments & $28.93^{* * * *}$ \\
Network investments & $29.17^{* * *}$ \\
Airport investments & $30.01^{* * *}$ \\
\hline
\end{tabular}

Note: $* * *$ statistical significance at $1 \%$.

Table 3 shows the results of various specification tests. First, the Breusch-Pagan Lagrange multiplier test for random effects with the null hypothesis that random effects are statistically significant. Second, the Wooldridge test for autocorrelation in panel data with the null hypothesis of no first order autocorrelation. The Breusch-Pagan test for random effects shows the existence of panel effects so that the pooled model cannot be applied. The Wooldridge test shows the existence of first order autocorrelation, which needs to be corrected. Note that the Hausman test with the null hypothesis of no differences between the random- and fixed-effects models cannot be applied here because some of the explanatory variables are time-invariant. Thus, the Hausman test will clearly find differences between the random- and the fixed-effects models.

Indeed, the use of a fixed-effects model is not appropriate in our context since this technique excludes anything that is time-invariant from the model - such as our key variable here, the 
distance from Madrid, or the fact of being a province with jurisdiction over network modes. However, the random-effects model might also be inconsistent should some of the explanatory variables be correlated with the random effects (and the Hausman test is not useful here to check the validity of the random-effects model). An alternative test is the Hausman-Taylor estimator, which allows the effect of time-invariant variables to be identified, while also accounting for explanatory variables that are correlated with the random effects. However, our preferred method is the random-effects model because this technique may correct the autocorrelation of the error term. In any case, our main results are not altered if we use either the Random-effects or the Hausman-Taylor model.

Table 4 shows the results of the estimation of Models (1-3) using two different estimation techniques. First, we present the results of the estimates when using generalized least squares (GLS) with random effects and a first-order autoregressive AR(1) disturbance (Column 1). Additionally, we also provide the results when using the Hausman-Taylor estimator (Column 2). In the latter case, we assume that one time-invariant variable (Land) is correlated with the random effects and two time varying variables are correlated with the random effects (Population and the lag of GDP per capita). Table 5 shows the estimated elasticities of the variables of distance from the capital and GDP per capita evaluated at the sample means.

Recall that Model (1) uses the total investment equation, considering all transportation modes, as its dependent variable, while Models (2) and (3) use investment in network modes and non-network modes (airports), respectively, as their dependent variables so that we can identify differences in the investment patterns between the two modes. In this regard, we are not able to model investment decisions in network and non-network modes as a simultaneous choice because investments in network modes are funded generally though the public budget, while investments in airports are usually funded through user fees. Note that according to our findings in Table 4, most of Model (1)'s (aggregate investment) results are driven by network modes.

Our results for total investment per capita confirm the centralization hypothesis by finding a negative and highly statistically significant impact of the variable capturing the distance from the political capital. ${ }^{7}$ Thus, regions close to Madrid appear to be the recipients of more investment effort than is the case of the more distant-lying regions. We find the same result when the dependent variable considered is investment in network modes. The use of different estimation techniques (GLS with random effects or Hausman-Taylor) does not alter the sign or the statistical significance of the coefficient associated with this variable when we consider total investment or investment in network modes. In terms of elasticities, a 10 per cent increase in the distance from the capital results in a 4-6 per cent fall in central government investment.

The investment allocation pattern for airports is less clear. In fact, we find that distant regions receive more investment efforts per capita when we use the GLS with random effects, but that the coefficient associated with this variable is not statistically significant when we use the Hausman-Taylor estimator. In any case, the total investment results are clearly driven by the allocation pattern for network modes.

Furthermore, we find that regions with higher GDP per capita have received greater amounts of investment per capita. This is consistent with the results obtained in Castells and Solé-Ollé (2005) and Solé-Ollé (2010), but they differ from those reported by Kemmerling and Stephan (2010). Indeed, we found a statistically significant relationship for this coefficient, which

\footnotetext{
${ }^{7}$ One could wonder whether other interpretations could be made for this result, such as fostering economies of agglomeration by means of a hub and spoke logic centred in Madrid, as suggested by one referee. Recall, however, that the financial and economic results of transportation services offered, as well as the discussion on infrastructure policy in Section 3 are consistent with our interpretation of centralization as a key political rationale for that policy. And so is the historical documentation for infrastructure policy over the last three centuries in Spain, presented in Bel (2010, 2011, 2012).
} 
Table 4. Determinants of the regional allocation of investments per capita in transport infrastructure

\begin{tabular}{|c|c|c|}
\hline Model (1): Total investments & $\begin{array}{c}\text { GLS random effects (AR1) } \\
{[1]}\end{array}$ & $\begin{array}{c}\text { Hausman-Taylor } \\
{[2]}\end{array}$ \\
\hline Distance_capital & $\begin{array}{l}-0.1668 * * \\
(0.0670)\end{array}$ & $\begin{array}{l}-0.2350 \text { *** } \\
(0.08)\end{array}$ \\
\hline Lag (GDP_per_capita) & $\begin{array}{l}0.0021^{* *} \\
(0.0008)\end{array}$ & $\begin{array}{l}0.0101 * * * \\
(0.0009)\end{array}$ \\
\hline Lag (Stock_capital) & $\begin{array}{l}0.00001 * * * \\
(3.21 \mathrm{e}-06)\end{array}$ & $\begin{array}{l}0.000010 * * * \\
(2.39 \mathrm{e}-06)\end{array}$ \\
\hline Land & $\begin{array}{c}0.0033 \\
(0.0025)\end{array}$ & $\begin{array}{c}-0.0031 \\
(0.006)\end{array}$ \\
\hline Population & $\begin{array}{r}-0.00001 \\
(.00001)\end{array}$ & $\begin{array}{c}0.000045 \\
(0.000063)\end{array}$ \\
\hline Votes_Incumbent_Party & $\begin{array}{r}-0.8597 \\
(.5436)\end{array}$ & $\begin{array}{l}1.12 * * \\
(0.55)\end{array}$ \\
\hline$D^{\text {foral }}$ & $\begin{array}{c}-133.00 * * * \\
(40.53)\end{array}$ & $\begin{array}{c}-145.60 * * \\
(59.47)\end{array}$ \\
\hline $\mathrm{N}$ & 1,174 & 1,174 \\
\hline $\mathrm{R}^{2}$ & 0.32 & - \\
\hline Wald $\mathrm{Chi}^{2}$ (joint sig.) & $54.53 * * *$ & $288.88 * * *$ \\
\hline Model (2): Network investments & {$[1]$} & [3] \\
\hline Distance_capital & $\begin{array}{l}-0.1557 * * * \\
(0.0655)\end{array}$ & $\begin{array}{c}-0.1841 * \\
(0.1070)\end{array}$ \\
\hline Lag(GDP_per_capita) & $\begin{array}{l}0.0019 * * \\
(0.0008)\end{array}$ & $\begin{array}{l}0.0095 * * * \\
(0.0009)\end{array}$ \\
\hline Lag(Stock_capital) & $\begin{array}{l}0.00001 * * * \\
(3.80 \mathrm{e}-06)\end{array}$ & $\begin{array}{l}0.000014 * * * \\
(2.90 \mathrm{e}-06)\end{array}$ \\
\hline Land & $\begin{array}{c}0.0033 \\
(0.0025)\end{array}$ & $\begin{array}{c}-0.0076 \\
(0.0072)\end{array}$ \\
\hline Population & $\begin{array}{c}-0.00002 * * \\
(0.00001)\end{array}$ & $\begin{array}{c}-0.000086 \\
(0.000062)\end{array}$ \\
\hline Votes_Incumbent_Party & $\begin{array}{l}-0.9205 \\
(0.5416)\end{array}$ & $\begin{array}{l}1.0091^{*} \\
(0.5498)\end{array}$ \\
\hline$D^{\text {foral }}$ & $\begin{array}{c}-136.80^{* * * *} \\
(39.72)\end{array}$ & $\begin{array}{c}-202.06^{* * * *} \\
(70.89)\end{array}$ \\
\hline $\mathrm{N}$ & 1,174 & 1,174 \\
\hline $\mathrm{R}^{2}$ & 0.35 & - \\
\hline Wald Chi2 (joint sig.) & $58.56 * * *$ & $271.18 * * *$ \\
\hline Model (3): Airports investments & [1] & [3] \\
\hline Distance_capital & $\begin{array}{l}0.0134 * * * \\
(0.0039)\end{array}$ & $\begin{array}{l}-0.0628 \\
(0.1083)\end{array}$ \\
\hline Lag(GDP_per_capita) & $\begin{array}{l}0.0002 * * * \\
(0.0000)\end{array}$ & $\begin{array}{c}0.000091 * \\
(0.000055)\end{array}$ \\
\hline Lag(Stock_capital) & $\begin{array}{l}9.40 \mathrm{e}-06^{* * *} \\
(1.81 \mathrm{e}-06)\end{array}$ & $\begin{array}{c}-1.02 \mathrm{e}-06 \\
(1.07 \mathrm{e}-06)\end{array}$ \\
\hline Land & $\begin{array}{c}-0.0003 \\
(0.0002)\end{array}$ & $\begin{array}{c}0.0011 \\
(0.0054)\end{array}$ \\
\hline Population & $\begin{array}{l}7.25 \mathrm{e}-06^{* * * *} \\
(1.17 \mathrm{e}-06)\end{array}$ & $\begin{array}{l}0.00011 * * * \\
(4.24 \mathrm{e}-06)\end{array}$ \\
\hline Votes_Incumbent_Party & $\begin{array}{c}0.0539 \\
(0.0513)\end{array}$ & $\begin{array}{l}0.1098 \\
(0.037) * * *\end{array}$ \\
\hline $\mathrm{N}$ & 1,174 & 1,174 \\
\hline $\mathrm{R}^{2}$ & 0.53 & - \\
\hline Wald Chi2 (joint sig.) & $119.64 * * *$ & 880.55 \\
\hline
\end{tabular}

Notes: Standard errors in parenthesis (robust to heteroscedasticity). ***,**, * statistical significance at $1 \%, 5 \%$ and $10 \%$ respectively. 
Table 5. Estimated elasticities for redistribution and centralization objectives 1981-2005

\begin{tabular}{lcc}
\hline & GLS random effects (AR1) & Hausman-Taylor \\
\hline Total investments & $-0.4736^{* *}$ & \\
Distance_capital & $0.1655^{* *}$ & $-0.6770^{* * * *}$ \\
GDP_per_capita & & $0.7996^{* * *}$ \\
Network investments & $-0.4565^{*}$ & $-0.54^{*}$ \\
Distance_capital & $0.1601^{* *}$ & $0.77 * * *$ \\
GDP_per_capita & & -6.30 \\
Airport Investments & $0.9479^{* * *}$ & 0.25 \\
Distance_capital & $0.4088^{* * *}$ & \\
GDP_per_capita & & \\
\hline Note: $* * *, * *, *$ & statistical significance at $1 \%, 5 \%$ and $10 \%$ respectively.
\end{tabular}

implies that greater investment efforts were made in rich provinces than in poor regions contradicting funding arguments based on solidarity.

However, the computation of elasticities (Table 5) provides evidence of some form of redistribution. Although richer regions receive more investments per capita than do poorer areas, the elasticity of the lag of GDP per capita is lower than 1, indicating that the increase in investment per capita is less than proportional. In spite of this, it might be argued that the positive relationship found with the lag of GDP could be attributable to a central government allocating investment for efficiency purposes. The reality, however, would seem to indicate a different story for Spain. First, the State's infrastructure policy has resulted in an extremely extensive high speed rail (HSR) network in kilometres; second only to China's in 2010, whereas the ratio passengers/HSR kilometre is more than 20 times greater in Japan, six times greater in France, and five times greater in Germany (Albalate and Bel 2011). Second, the Spanish public monopoly operating the State's main airports, AENA, has recorded the greatest losses in the world over the last few years (Bel and Fageda 2011). Clearly, efficiency has not been a primary driver of infrastructure policy in Spain.

The coefficient associated with the stock of capital is positive and statistically significant when we consider both total investment and investment in network modes as dependent variables. This holds true regardless of the estimation techniques used. The coefficient is also positive and statistically significant when we consider investment in airports as the dependent variable and use GLS with random effects and fixed effects as estimation techniques.

The coefficient associated with the number of electoral votes received in a given province by the incumbent party in central government is positive and statistically significant only in the regression that uses the Hausman-Taylor estimator. This is true for all dependent variables considered. Thus, we need to exercise caution when interpreting the results for this variable. Note that previous studies have typically employed a variable indicating the difference, at the provincial level, in the votes received by the two main parties at the national elections. Within a proportional electoral system such as that operated by Spain, the so-called 'swing voter' hypothesis is less important, while the support that the incumbent party in central government receives in a province becomes more relevant. ${ }^{8}$

\footnotetext{
${ }^{8}$ We have experimented with other political variables like a dummy variable that takes the value of 1 in those provinces where there is a correspondence between the incumbent party in the central government and the incumbent party in the regional government. This variable cannot be included in our specification because of its high collinerity with the Votes variable. For this reason we provide results with this variable included instead of the 'votes' variable in the appendix (Table A2). The coefficient of this variable is statistically insignificant across all models.
} 
We find no clear evidence that mobility needs act as determinants of the investment made by central government in network modes. Indeed, the coefficients associated with the Land and Population variables are generally not statistically significant when we consider both total investment and investment in network modes as dependent variables. By contrast, the coefficient associated with the Population variable is positive and statistically significant when we use investment in airports as the dependent variable. Hence, we can conclude that mobility needs may drive investments in the case of infrastructures that are financed with user fees (as is the case of airports), while this would seem not to be the case when infrastructure is financed through public budgets (as is the case of roads and rail).

Finally, the importance of using a variable denoting those regional governments that have jurisdiction over their network modes should be noted. The highly significant coefficient recorded confirms that central government reduces its investment efforts when such powers have been transferred to regional governments.

In the appendix (Table A1), we show additional regressions with total investment per capita as the dependent variable. Here, we differentiate between two periods in which a different political party was in central government: the socialist party (PSOE) in the first period (19831996) and the conservative Popular Party (PP) in the second period (1997-2005). ${ }^{9}$ In this way we are able to verify whether our results are consistent for periods in which parties of different political ideology held power. Our results in Table A1 show that a centralization strategy has been adopted by both political parties. However, the conservative party (PP) seems to have given even greater priority to this goal, as the statistical significance and the estimated elasticity of the distance from the capital variable are higher when the estimation is made for the period 1997-2005. Interestingly, the coefficient associated with the GDP per capita variable is positive and statistically significant in both periods. However, the estimated elasticity for this variable is lower than 1 when the socialist party was in government and higher than 1 when the conservative party was in power.

\section{Concluding remarks}

The literature examining the determinants of the regional allocation of infrastructure investment shows that efficiency and redistribution are important drivers of the decisions taken by central governments. Additionally, political factors, such as electoral strength and party alignment, have been shown to play a role. However, it is our claim that greater attention needs to be paid to factors associated with broader political objectives that the central government sets itself and seeks to implement through specific policies such as infrastructure investment.

Our results for those variables traditionally dealt with in the literature (both economic and political) are generally consistent with previous empirical evidence. Yet, regarding our main empirical contribution, we find that investment in surface network modes is influenced by the centralization strategy of investing near to the political capital. This pattern, however, is less clear when we consider the investment effort in non-network modes. Since investment in surface network transportation infrastructure is much higher than that in airports and ports, we suggest that centralization has been a principal driver of central government's regional allocation of investment.

In short, the Spanish case would seem to illustrate the fact that centralization can act as a major driver of the allocation of surface transportation infrastructure. Moreover, it may well be

\footnotetext{
9 Although the PSOE won the 1982 election, the first public budget drafted and executed by the government did not appear until 1983. For this same reason, the 2005 investments correspond to the PP government that drew up the budget in 2004, although it was executed by the incoming PSOE government in 2005.
} 
the case that what has traditionally been classed as redistribution is in fact a policy that also seeks to connect the capital (the geographical centre) to the peripheral regions by means of transport infrastructure. Overall, our analysis shows that above and beyond considerations of efficiency and equity, central governments may pursue other objectives in their regional allocation of investment.

\section{References}

Albalate D, Bel G (2011) Cuando la economía no importa: Auge y esplendor de la Alta Velocidad en España. Revista de Economía Aplicada 19: 171-190

Bel G (2010) España, capital París. Destino, Barcelona

Bel G (2011) Infrastructure and nation building: The regulation and financing of network transportation infrastructures in Spain (1720-2010). Business History 53: 688-705

Bel G (2012) Infrastructure and the political economy of national building in Spain, 1720-2010. Sussex Academic Press, London

Bel G, Fageda X (2009) Preventing competition because of solidarity: Rhetoric and reality of airport investments in Spain. Applied Economics 41: 2853-2865

Bel G, Fageda X (2011) La reforma del modelo de gestión de aeropuertos en España: ¿Gestión conjunta o individual? Hacienda Pública Española/Revista de Economía Pública 196: 109-130

Bilotkach V (2010) Political economy of infrastructure investment: Evidence from ARRA airport grants. Working paper, University of California, Irvine

Cadot O, Hendrik-Roller L, Stephan A (2006) Contribution to productivity or pork barrel? The two faces of infrastructure investment. Journal of Public Economics 90: 1133-1153

Castillo-Manzano JI, Fageda X (2010) How should investments be allocated in a publicly-owned port system? Political lobbying vs. economic criteria. Working paper, University of Barcelona

Castells A, Solé-Ollé A (2005) The regional allocation of infrastructure investment: The role of equity, efficiency and political factors. European Economic Review 49: 1165-1205

de la Fuente A (2004) Second-best redistribution through public investment: A characterization, an empirical test and an application to the case of Spain. Regional Science and Urban Economics 34: 489-503

Docwra GE, Kolsen HM (1989) Transport and Australian federalism 1901-1972. Journal of Transport History 10: 59-73

Faguet JP (2004) Why so much centralization? A model of primitive centripetal accumulation. Research Paper No. DEDPS 43, London School of Economics, London

Fleming FJ (1991) Profits and visions: British capital and railway construction in Argentina, 1854-1886. In: Davis CB, Wilburn KE, Robinson RE (eds) Railway imperialism. Greenwood Press, New York

Gray I (2009) Maintaining the power of central governments: Regional land transport in the Australian Federation, 1850-2007. Journal of Transport History 30: 22-39

Kemmerling A, Stephan A (2002) The contribution of local public infrastructure to private productivity and its political economy: Evidence from a panel of large German cities. Public Choice 113: 403-424

Kemmerling A, Stephan A (2010) The determinants of regional transport investment across Europe. In: Bosch N, Espasa M, Solé-Ollé A (eds) The political economy of inter-regional fiscal flows. Edward Elgar, Cheltenham

Knight B (2004) Parochial interests and the centralized provision of local public goods: Evidence from congressional voting on transportation projects. Journal of Public Economics 88: 845-866

Emilio Pérez Touriño E (1994) Efectos del plan: Realizaciones y balance socioeconómico. Estudios de Transporte y Comunicaciones 65: 9-27

Smith A (1776) The wealth of nations. W. Strahan and T. Cadell, London

Solé-Ollé A (2010) The determinants of the regional allocation of infrastructure investment in Spain. In: Bosch N, Espasa M, Solé-Ollé A (eds) The political economy of inter-regional fiscal flows. Edward Elgar, Cheltenham

Wotherspoon G (1979) The determinants of the pattern and pace of railway development in New South Wales, 1850-1914. Australian Journal of Politics \& History 25: 51-65

Yamano N, Ohkawara T (2000) The regional allocation of public investment: Efficiency or equity? Journal of Regional Science 40: 205-229 


\section{Appendix}

Table A1. Determinants of the regional allocation of total investments per capita for different periods. GLS random effects (AR1)

\begin{tabular}{|c|c|c|c|c|}
\hline & \multicolumn{2}{|c|}{ 1983-1996 } & \multicolumn{2}{|c|}{ 1997-2005 } \\
\hline & Coefficient & Elasticity & Coefficient & Elasticity \\
\hline Distance_capital & $\begin{array}{c}-0.0558 * \\
(0.0331)\end{array}$ & $-0.25^{*}$ & $\begin{array}{l}-0.2596^{* *} \\
(0.1176)\end{array}$ & $-0.43^{* *}$ \\
\hline Lag (GDP_per_capita) & $\begin{array}{l}0.0086^{* * * *} \\
(0.0017)\end{array}$ & $0.73^{* * *}$ & $\begin{array}{l}0.0248 * * * \\
(0.0040)\end{array}$ & $1.69 * * *$ \\
\hline Lag (Stock_capital) & $\begin{array}{c}1.38 \mathrm{e}-06 \\
(3.43 \mathrm{e}-06)\end{array}$ & 0.02 & $\begin{array}{l}1.87 \mathrm{e}-06^{* * * *} \\
(4.59 \mathrm{e}-06)\end{array}$ & 0.03 \\
\hline Land & $\begin{array}{l}0.00256^{*} \\
(0.0013)\end{array}$ & $0.35^{*}$ & $\begin{array}{c}0.0065 \\
(0.0045)\end{array}$ & 0.32 \\
\hline Population & $\begin{array}{c}-8.40 \mathrm{e}-06^{*} \\
(5.24 \mathrm{e}-06)\end{array}$ & -0.08 & $\begin{array}{l}-0.000045 \\
(0.000017)^{* *}\end{array}$ & $-0.17 * *$ \\
\hline Votes_Incumbent_Party & $\begin{array}{c}-0.6793 \\
(0.6243)\end{array}$ & -0.37 & $\begin{array}{c}-1.23 \\
(1.10)\end{array}$ & -0.24 \\
\hline$D^{\text {foral }}$ & $\begin{array}{l}-65.35^{* * * *} \\
(19.64)\end{array}$ & $-0.07 * * *$ & $\begin{array}{c}-304.45^{* *} \\
(72.83)\end{array}$ & $-0.12^{* * *}$ \\
\hline $\mathrm{N}$ & \multicolumn{2}{|c|}{658} & \multicolumn{2}{|l|}{423} \\
\hline $\mathrm{R}^{2}$ & \multicolumn{2}{|c|}{0.25} & \multicolumn{2}{|l|}{0.28} \\
\hline Wald Chi2 (joint sig.) & \multicolumn{2}{|c|}{$66.72 * * *$} & \multicolumn{2}{|l|}{$61.43 * * *$} \\
\hline
\end{tabular}

Note: Standard errors in parenthesis (robust to heteroscedasticity). ***,**,* statistical significance at $1 \%, 5 \%$ and $10 \%$ respectively.

Table A2. Determinants of the regional allocation of investments per capita in transport infrastructure

\begin{tabular}{lc}
\hline Model (1): Total investments & GLS random effects (AR1) \\
\hline Distance_capital & $-0.1673^{* *}$ \\
& $(0.0676)$ \\
Lag (GDP_per_capita) & $0.0022^{* *}$ \\
& $(0.0009)$ \\
Lag (Stock_capital) & $0.00001^{* * *}$ \\
& $(3.21 \mathrm{e}-06)$ \\
Land & 0.0028 \\
& $(0.0025)$ \\
Population & -0.00001 \\
& $(0.00001)$ \\
Correlation regional-central government & -0.3634 \\
& $(0.9209)$ \\
$D^{\text {foral }}$ & $-123.00 * * *$ \\
& $(47.37)$ \\
N & 1,174 \\
$\mathrm{R}^{2}$ & 0.30 \\
Wald Chi2 (joint sig.) & $52.17 * * *$ \\
\hline
\end{tabular}


Table A2. Continued

\begin{tabular}{|c|c|}
\hline Model (2): Network investments & {$[2]$} \\
\hline Distance_capital & $\begin{array}{c}-0.1563 * * * \\
(0.0669)\end{array}$ \\
\hline Lag(GDP_per_capita) & $\begin{array}{l}0.0020 * * \\
(0.0008)\end{array}$ \\
\hline Lag(Stock_capital) & $\begin{array}{l}0.00001 * * * \\
(3.82 \mathrm{e}-06)\end{array}$ \\
\hline Land & $\begin{array}{c}0.0028 \\
(0.0025)\end{array}$ \\
\hline Population & $\begin{array}{c}-0.00002 * \\
(0.00001)\end{array}$ \\
\hline Correlation regional-central government & $\begin{array}{c}-0.6527 \\
(0.9185)\end{array}$ \\
\hline$D^{\text {foral }}$ & $\begin{array}{c}-121.27 * * \\
(46.92)\end{array}$ \\
\hline $\mathrm{N}$ & 1,174 \\
\hline $\mathrm{R}^{2}$ & 0.32 \\
\hline Wald Chi2 (joint sig.) & $55.38 * * *$ \\
\hline Model (3): Airports investments & [3] \\
\hline Distance_capital & $\begin{array}{l}0.0101 * * \\
(0.0043)\end{array}$ \\
\hline Lag(GDP_per_capita) & $\begin{array}{l}0.0002^{* * *} \\
(0.0000)\end{array}$ \\
\hline Lag(Stock_capital $)$ & $\begin{array}{l}7.01 \mathrm{e}-06 * * * \\
(1.38 \mathrm{e}-06)\end{array}$ \\
\hline Land & $\begin{array}{c}-0.0001 \\
(0.0002)\end{array}$ \\
\hline Population & $\begin{array}{l}7.23 \mathrm{e}-06 * * * \\
(6.76 \mathrm{e}-07)\end{array}$ \\
\hline Correlation regional-central government & $\begin{array}{c}0.3817 \\
(0.6775)\end{array}$ \\
\hline $\mathrm{N}$ & 1,174 \\
\hline $\mathrm{R}^{2}$ & 0.76 \\
\hline Wald Chi2 (joint sig.) & $165.33 * * *$ \\
\hline
\end{tabular}

Note: Standard errors in parenthesis (robust to heteroscedasticity). ***, **, * statistical significance at $1 \%, 5 \%$ and $10 \%$ respectively. 